\title{
A Longitudinal Study of the Content Validity of the Writing Part in TEM4 (2008-2017)*
}

\author{
Peirong Yang \\ Foreign Language School of Anhui Sanlian University \\ Hefei, China 230601
}

\begin{abstract}
This paper takes the TEM4 writing parts from 2008 to 2017 as the research object, aiming at exploring the content validity of the writing parts in TEM4 in the past ten years. The study finds that the writing parts in TEM4 in the past ten years not only reflect the concept of the "Syllabus", but also coincide with the "Examination Outline". But the genre examined is too singular, and the form of information provision is basically the outline type. There is still much room for improvement in the content validity of the writing part. Based on this, this paper attempts to provide some suggestions for the TEM4 writing part thesis assignment and English professional writing teaching for reference by relevant personnel.
\end{abstract}

Keywords-TEM4 writing part; content validity; diachronic research

\section{INTRODUCTION}

According to the "Outline of the Test for English MajorsBand 4" (hereinafter referred to as the "Examination Outline"), TEM4 aims to assess the ability of second-year English majors to comprehensively apply basic English skills and students' mastery of English knowledge in pronunciation, vocabulary, grammar and discourse. The test is a standard reference teaching inspection exam. It covers listening, reading and writing skills as well as grammar and vocabulary knowledge. Among them, the writing part examines students' ability to use English to express their ideas. Professor Li Xiaoju pointed out: "Writing test is one of the tests that are most likely to get the maximum validity in modern language tests" [1]. So, what is the validity of the TEM4 writing parts in the past ten years? Can the writing test really test the ability of candidates to use English to express their ideas? This paper intends to conduct a diachronic study on the 2008-2017 TEM4 writing parts, and explore the content validity of the writing parts, aiming to provide relevant suggestions for the TEM4 writing part thesis assignment, English professional writing teaching and student preparation.

\section{RESEARCH DESIGN}

Bachman believes that validity is the basic starting point of language testing and is the core [2]. He divided the validity

*Fund Project: Key Project of Humanities and Social Sciences Research of Universities in Anhui Province: "An Empirical Study on the Washback of TEM4" (Project No.: SK2018A0673); Teaching Quality and Teaching Reform Project of Anhui Sanlian University (Project No.: 17zlgc009). of language tests into five categories: content validity, structural validity, standard associated validity, predictive validity, and surface validity. Regarding the framework of validity studies, Bachman \& Palmer proposed a test task feature framework in their research [3]. The framework divides test methods from five aspects, namely the test environment, test descriptions, test input information, expected answers to input information, and the relationship between input information and answers. Based on Bachman \& Palmer's test task feature framework, this paper analyzes the content validity of TEM4 writing parts from the perspective of test input information. Here, the test input information mainly includes three aspects: the theme of the test, the writing genre and the form of information provision. The specific analysis framework is shown in "Table I".

\section{TABLE I. ANALYSIS FRAMEWORK OF TEM4 WRITING PARTS FOR 2008-2017}

\begin{tabular}{|l|l|}
\hline \multicolumn{1}{|c|}{$\begin{array}{c}\text { Analysis } \\
\text { Dimension }\end{array}$} & \multicolumn{1}{c|}{ Main Content } \\
\hline $\begin{array}{l}\text { The theme of the } \\
\text { question }\end{array}$ & $\begin{array}{l}\text { Campus life and learning, daily life, } \\
\text { traditional culture, social hotspots } \\
\text { and focus }\end{array}$ \\
\hline Writing genre & $\begin{array}{l}\text { argumentative writing, expository- } \\
\text { writing,narrative, descriptive, } \\
\text { applicative writing }\end{array}$ \\
\hline $\begin{array}{l}\text { Information } \\
\text { provision form }\end{array}$ & $\begin{array}{l}\text { Outline, picture type, chart type, } \\
\text { text type, etc. }\end{array}$ \\
\hline
\end{tabular}

\section{RESULTS AND DISCUSSIONS}

The basic information of the 2008-2017 TEM4 writing test questions is shown in "Table II". In general, first of all, the subjects of the questions in the past ten years are closely related to the daily life and study of the candidates. Secondly, the genres examined are argumentative writing and expository-writing. Finally, regarding the form of information provision, it can be seen from the table below that before the reform in 2016, the form of information provision for compositions with assigned subjects was mainly background introduction + outline, and the form after the reform was excerpt material + outline. After the reform, the writing part not only examines the writing ability of candidates, but also examines their reading comprehension ability and summary ability. 
TABLE II. BASIC INFORMATION TABLE FOR TEM4 WRITING QUESTIONS FOR 2008-2017

\begin{tabular}{|c|c|c|c|}
\hline Year & Theme & Genre & $\begin{array}{c}\text { Information } \\
\text { Provision Form }\end{array}$ \\
\hline 2017 & $\begin{array}{l}\text { Comment on "Whether the } \\
\text { human brain will become } \\
\text { lazy in the world where } \\
\text { smart machines are } \\
\text { operating" }\end{array}$ & $\begin{array}{l}\text { Argume } \\
\text { ntative } \\
\text { writing }\end{array}$ & $\begin{array}{l}\text { Excerpt material } \\
+ \text { outline }\end{array}$ \\
\hline 2016 & $\begin{array}{l}\text { Comment on "Whether } \\
\text { parents should take their } \\
\text { children to vacation in the } \\
\text { middle of the semester in } \\
\text { order to save money" }\end{array}$ & $\begin{array}{l}\text { Argume } \\
\text { ntative } \\
\text { writing }\end{array}$ & $\begin{array}{l}\text { Excerpt material } \\
+ \text { outline }\end{array}$ \\
\hline 2015 & $\begin{array}{l}\text { Interpret "How do I deal with } \\
\text { stress issues?" }\end{array}$ & $\begin{array}{l}\text { Argume } \\
\text { ntative } \\
\text { writing }\end{array}$ & $\begin{array}{l}\text { Background } \\
\text { introduction } \\
\text { outline }\end{array}$ \\
\hline 2014 & $\begin{array}{l}\text { Comment on "Whether } \\
\text { English Majors Should Learn } \\
\text { Mathematics" }\end{array}$ & $\begin{array}{l}\text { Argume } \\
\text { ntative } \\
\text { writing }\end{array}$ & $\begin{array}{l}\text { Background } \\
\text { introduction } \\
\text { outline }\end{array}$ \\
\hline 2013 & $\begin{array}{l}\text { Comment on "Some people } \\
\text { think that the use of coupons, } \\
\text { group purchases, etc. Are } \\
\text { unwise consuming } \\
\text { behaviors." }\end{array}$ & $\begin{array}{l}\text { Argume } \\
\text { ntative } \\
\text { writing }\end{array}$ & $\begin{array}{l}\text { Background } \\
\text { introduction } \\
\text { outline }\end{array}$ \\
\hline 2012 & $\begin{array}{l}\text { Explain how you celebrate } \\
\text { the "Dragon Boat Festival" }\end{array}$ & $\begin{array}{l}\text { Exposit } \\
\text { ory- } \\
\text { writing }\end{array}$ & $\begin{array}{l}\text { Background } \\
\text { introduction } \\
\text { outline }\end{array}$ \\
\hline 2011 & $\begin{array}{l}\text { Comment on "whether } \\
\text { private cars should pay taxes } \\
\text { due to their environmental } \\
\text { pollution" }\end{array}$ & $\begin{array}{l}\text { Argume } \\
\text { ntative } \\
\text { writing }\end{array}$ & $\begin{array}{l}\text { Background } \\
\text { introduction } \\
\text { outline }\end{array}$ \\
\hline 2010 & $\begin{array}{l}\text { Comment on "whether } \\
\text { college students should hire } \\
\text { cleaners" }\end{array}$ & $\begin{array}{l}\text { Argume } \\
\text { ntative } \\
\text { writing }\end{array}$ & $\begin{array}{l}\text { Background } \\
\text { introduction } \\
\text { outline }\end{array}$ \\
\hline 2009 & $\begin{array}{l}\text { Comment on "whether } \\
\text { tourism will do harm to the } \\
\text { environment" }\end{array}$ & $\begin{array}{l}\text { Argume } \\
\text { ntative } \\
\text { writing }\end{array}$ & $\begin{array}{l}\text { Background } \\
\text { introduction } \\
\text { outline }\end{array}$ \\
\hline 2008 & $\begin{array}{l}\text { Comment on "the benefits of } \\
\text { volunteering" }\end{array}$ & $\begin{array}{l}\text { Argume } \\
\text { ntative } \\
\text { writing }\end{array}$ & $\begin{array}{l}\text { Background } \\
\text { introduction } \\
\text { outline }\end{array}$ \\
\hline
\end{tabular}

a. Note: Before the reform of TEM4 in 2016, the composition was divided into two parts: writing with assigned subject and note writing. This article only studied the writing with assigned subject

\section{A. Themes of Test Questions}

As can be seen from "Table II", the TEM4 writing parts of 2008-2017 cover a variety of topics, mainly related to university campus life and learning, traditional culture, social hotspots and focus. For example, the 2017 writing part requires candidates to express their opinions on whether our brains will become lazy in a world where smart machines are operating. As we all know, the arrival of the intelligent age is a double-edged sword, in the world where intelligent machines are running, whether the human brain will become lazy, this is a hot topic in society, which requires candidates to have critical thinking, to give their own views and the reasons. Another example is that the writing parts in 2009 and 2011 are all about environmental issues. In recent years, environmental protection has always been the focus. The tests with such themes reflect the training objective of the "Syllabus for English Teaching for English Majors in Colleges and Universities" (hereinafter referred to as the "Syllabus"), that is, to improve students' ideological and moral quality, cultural quality and psychological quality.
The study also finds that writing parts in the past decade have become more and more inclined to examine candidates' ability to deal with practical problems. For example, the writing part in 2015 requires candidates to explain their own ways to relieve stress. In another example, the 2013 writing part requires candidates to express their opinions on shopping with various coupons, participating in group purchases, etc. These are tests to examine candidates' ability to deal with practical problems. In short, the tests with such subjects have well reflected that required in the "Syllabus": "focus on cultivating students' ability to acquire knowledge, ability to think independently and ability to innovate". In addition, the writing topic in 2012 is the Dragon Boat Festival. This is a reflection of traditional culture and has a good guiding effect on candidates. It guides candidates to focus on and promote Chinese traditional culture.

According to the above analysis, the themes of the TEM4 writing parts in the past ten years are various, which are closely related to the daily life and learning of the candidates. This also embodies the provisions of the "Examination Outline", that is, the writing themes should be familiar to the candidates. It can be seen that the 2008-2017 TEM4 writing parts not only reflect the concept of the "Syllabus" but also coincide with the "Examination Outline". Therefore, from the perspective of writing themes, the content validity of the TEM4 writing parts in the past ten years is high, which has set an example for the assignment of themes of other writing tests.

\section{B. Writing Genres}

In 2016, the state carried out a major reform on TEM4. The writing part of the exam was divided into two parts: thesis writing and note writing. After the reform, the note writing was canceled, but the thesis writing has been greatly changed, and the excerpt materials have been added. Candidates are required to read the materials given and write on the basis of summarizing the materials. With regard to the writing genre, this article only studies the thesis writing parts of the past ten years. It can be seen from "Table II" that the genres of the thesis writing parts in the past ten years involve two kinds: argumentative writing and expository-writing, and are mainly argumentative writings (nine times). For example, in the 2016 writing part, candidates are required to read the excerpts and express their views on whether parents should take their children to vacation in the middle of the semester in order to save money. This topic is obviously the "yes" or "no" issue, and belongs to the genre of argumentative writing. Only the genre of the 2012 writing part is expository-writing, requiring candidates to explain how they celebrate the Dragon Boat Festival.

The "Examination Outline" clearly states that the writing part is thesis writing, and the genres of the writings should be mainly expository-writing, argumentative writing or narrative. The argumentative writing has appeared nine times in the writing parts in the past ten years, and expository-writing has appeared once, which has a negative backwash effect on the daily writing teaching for English majors. It will mislead teachers and students to focus on the genres examined and ignore other genres. Therefore, from this perspective, the 
content validity of the TEM4 writing parts in the past decade needs to be improved.

\section{Form of Information Provision}

It can be seen from Table II that before the reform in 2016, the information provision form of the thesis writing part was the simple background introduction + outline. For example, in 2014, the background message of the writing part is: "An English major student complained in a letter to the principal that he had to take math classes. He felt that the language major students would not use mathematics. After the test, they will forget what they have learned. What do you think?" The writing part asks the candidates to state their opinions first, then propose one or two reasons to support their views, and finally summarize. Such information is provided in a simple and concise manner, and the prompts are clear. After reading the background information, the students can start writing according to the given outline, and avoid writing articles at will.

After the 2016 reform, the information provision form in the writing part has become the material + outline, requiring candidates to summarize the materials given first, and then write articles according to the outline. For example, in 2016, the title of the excerpt in the writing part is: Term-time holiday will be banned. Candidates are required to summarize the excerpts first, and then comment on whether parents should take their children to travel during the term time to save money. For this topic, in the first paragraph, candidates can summarize the material, explain the social phenomenon and point out that the UK will introduce a penal policy. In the second paragraph, it is advisable to discuss the behaviors of such parents. Candidates can choose either view of the two parties and provide reasons to support their views. In the third paragraph, candidates can summarize the whole articles and re-emphasizes their own points of views. From the perspective of the reformed writing part, this part comprehensively examines students' reading comprehension ability, material summarizing ability and writing ability.

The "Examination Outline" points out that the writing part mainly examines whether the candidate can write an article according to the given writing topic, chart or reading materials. In my opinion, the information provision forms in the writing parts in the past ten years are relatively single, involving only the simple outline type and the material reading type that emerged after the 2016 reform. The information provision forms in the writing parts can be various, such as the picture type, graphic type, or a simple combination like material + chart. Therefore, from the perspective of the form of information provision, there is still much room for improvement in the content validity of TEM4 writing parts in the past decade.

\section{CONCLUSION}

Through the diachronic study on the content validity of the TEM4 writing parts in 2008-2017, it is found that the content validity of the writing parts in the past ten years needs to be improved, which is embodied in two aspects: (1) The genre examined is too single, which has not fully reflected the concept of "Syllabus" and "Examination Outline", and has a negative reversal effect on the writing teaching for English majors. (2) As far as the information provision form, before the reform, it was the simple background introduction + outline, and after the reform, it has become the excerpt material + outline. Although the material reading has been added to the writing part after the reform, the form of information provision is still relatively single, which does not coincide with the content of the "Syllabus". Although there is some room for improvement in the TEM4 writing parts in the past ten years, there are also outstanding places, such as the writing themes of the tests, the themes are diverse and educational, and are closely related to the daily life and learning of the candidates, which not only reflects the concept of the "Syllabus", but also coincides with the "Examination Outline". They are worthy of reference for other exams.

Based on the above discussion, this paper will put forward some suggestions for the TEM4 writing part thesis assignment and English professional writing teaching for the reference of relevant personnel.

\section{A. About the Thesis Assignment of the TEM4 Writing Part}

1) The genres examined should be diversified: The genres examined should not be limited to one or two types, and they should be diversified. If there are only one or two types, it will bring negative reversal effect to English majors in the teaching and learning of English writing, misleading teachers and students to only pay attention to the examined genres and ignore other genres.

2) Combine multiple forms of information provision: The form of information provision in the writing part can be a chart, a picture, a reading material, an outline, etc., and in particular, it can be a combination of various forms. The combination form is novel, contains a large amount of information, and can examine students' various abilities from all aspects.

\section{B. About English Professional Writing Teaching}

1) Develop good writing habits: In writing teaching, teachers should guide students to carefully understand the writing theme and make outlines before writing, and check their articles after completing writing, that is, follow the three processes of English writing: pre-writing, writing and revising, to cultivate students' good writing habits.

2) Pay attention to the cultivation of students' ability to think and analyse: The reason why students' writing ability is not strong is not only that the students' language foundation is weak, but more importantly, it is that the students generally lack the ability to think and analyze, and a large number of students are "lacking the ability to think and analyze" [4]. Teachers should consciously cultivate students' ability to learn independently, encourage students to accumulate extracurricular knowledge, broaden their horizons, and cultivate their ability to think and analyze.

3) Rewriting the texts or writing abstracts: The reformed writing part requires candidates to summarize the excerpts 
and then write articles according to the outline. For such requirements, teachers are advised to instruct students to rewrite the texts in their own expressions or to summarize the texts in their own expressions after understanding the texts. Students can improve their writing skills by rewriting the text or writing a summary of the text.

\section{REFERENCES}

[1] Li Xiaoju. Language Test Science and Art [M]. Changsha: Hunan Education Press, 1997:406.

[2] Bachman, L. F. Fundamental Considerations in Language Testing [M]. Oxford: Oxford University Press, 1999: 152.

[3] Bachman, L. F. \& Plamer, A. Language Testing in Practice [M]. Shanghai: Foreign Language Teaching and Research Press, 1999:103.

[4] Wang Chang, Ran Xiuxia. Cultivation of students' ability to think and analyse in writing teaching for TEM-4[J]. Journal of Sichuan Tourism Institute, 2017(2): pp.97-100. 